OPEN ACCESS

Citation: Wong S.Y., Boyce P.C. (2021) Studies on Homalomeneae (Araceae) of Borneo XXVII: A new Homalomena [Chamaecladon Clade] endemic to the Santubong Peninsula. Webbia. Journal of Plant Taxonomy and Geography 76(1): 83-87. doi: 10.36253/jopt-10339

Received: January 14, 2021

Accepted: February 15, 2021

Published: April 27, 2021

Copyright: (C2021 Wong S.Y., Boyce P.C. This is an open access, peer-reviewed article published by Firenze University Press (http://www.fupress.com/webbia) and distributed under the terms of the Creative Commons Attribution License, which permits unrestricted use, distribution, and reproduction in any medium, provided the original author and source are credited.

Data Availability Statement: All relevant data are within the paper and its Supporting Information files.

Competing Interests: The Author(s) declare(s) no conflict of interest.

Editor: Niels Weessies

ORCID

WSY: https://orcid.org/0000-0003-40429672

PCB: https://orcid.org/0000-0002-58569561

\section{Studies on Homalomeneae (Araceae) of Borneo XXVII: A new Homalomena [Chamaecladon Clade] endemic to the Santubong Peninsula}

\author{
Wong Sin Yeng ${ }^{1,2,3 *}$, Peter C. Boyce ${ }^{3}$ \\ ${ }^{1}$ Institute of Biodiversity and Environmental Conservation, Universiti Malaysia Sarawak \\ 94300 Kota Samarahan, Sarawak, Malaysia \\ ${ }^{2}$ Harvard University Herbaria, 22 Divinity Avenue, Cambridge, MA 02138, USA \\ ${ }^{3}$ Department Biologie I, Systematische Botanik und Mykologie, Ludwig-Maximilians- \\ Universität München, München, Germany \\ ${ }^{\star}$ Corresponding author. E-mail: sywong@unimas.my
}

\begin{abstract}
A new species of Homalomena Chamaecladon Clade is described from the Santubong Peninsula, Kuching Division, Sarawak, to where it is endemic, and compared with $H$. paucinervia from the nearby Matang Massif, and with $H$. atrox from Sri Aman, the two other most similar described species from NW Borneo. All three species are illustrated from living plants, and keyed-out.
\end{abstract}

Keywords: Araceae, Homalomena, Chamaecladon clade, Sarawak, Borneo, Paleogene sandstones.

\section{INTRODUCTION}

Homalomena is one of the largest genera of aroids occurring on Borneo, with 64 accepted species, and with at least twice that number yet to be described (Boyce \& Croat 2011). Species of the Homalomena Chamaecladon clade (sensu Wong et al. 2013) are distinctive by the spathe lacking a constriction and by having pistillate florets wherein the staminode is much shorter than the pistil. Currently the clade consists about 140 published names, of which about 40 are of unresolved status and 19 are confirmed synonyms. The clade occurs from Sumatera though to New Guinea, and as far north as southern Indochina. The principle areas of species' richness and diversity are Peninsular Malaysia and, especially, Sumatera wherein the diversity of form, especially epidermis ornamentation reaches extraordinary extremes (Wong et al. 2020). It is puzzling that Borneo, an island with a staggeringly rich aroid flora, appears to be much less provided for in species and with much lower diversity when it comes to the Chamaecladon clade.

Species of the Homalomena Chamaecladon clade (sensu Wong et al. 2013) occurring in NW Borneo pose taxonomic problems in part owing to misapplication of West Malaysian species' names to undescribed Bornean 
species and in part because species' boundaries remain poorly understood. The first species for the clade described from NW Borneo was $H$. paucinervia Ridl. (Ridley 1905), described from riverside rocks of the Matang Massif near Kuching. After that, save Furtado's stumbling attempt to clarify the taxonomy for Homalomena (Furtado 1939), no further taxonomic progress was made until the publication of $H$. atrox P.C.Boyce et al. (Boyce et al. 2010) for a facultative rheophyte from Batang Ai, Sri Aman Division, Sarawak.

Work began in earnest with Wong \& Boyce (2020) describing two species, Homalomena acuminata (Ridl.) S.Y.Wong \& P.C. Boyce and $H$. ridleyi S.Y.Wong \& P.C.Boyce for plants long-confused with Peninsular Malaysian H. griffithii (Schott) Hook.f. [Chamaecladon clade]. Here we continue with a new species from the Santubong peninsular hitherto assigned to Ridley's $H$. paucinervia from Matang

As has been noted in previous papers (e.g., Hay 1998, Boyce and Wong 2015, Kartini et al. 2015; Wong and Boyce 2020) the extraordinarily complex surface geology of the island of Borneo is enormously important in the separation of species in aroid genera such as Homalomena, Schismatoglottis, and Alocasia, among others. Geology in this paper is specified based on Hutchinson $(1989,2005)$ and Tate (2001).

1. Homalomena santubognensis S.Y.Wong \& P.C.Boyce, sp. nov.

Type: Malaysian Borneo. Sarawak, Kuching, Santubong N.P., Jungle Trail, Waterfall F1, $1^{\circ} 44^{\prime} 35.1^{\prime \prime} \mathrm{N}$ $110^{\circ} 19^{\prime} 23.9^{\prime \prime}$ E, $175 \mathrm{~m}$ asl., 19 Sep 2020, Wong Sin Yeng \& P.C.Boyce AR-2438 (holotype SAR!; isotype SAR - spirit!). (Figure 1 and $2 \mathrm{~A}$ ).

\section{Diagnosis}

Homalomena santubognensis is most similar to $H$. paucinervia but readily distinguished by the overall stouter spadix (spadix width $\times$ length $4 \mathrm{~mm} \times 1.9 \mathrm{~cm}$ [1:4.5] vs $3 \mathrm{~mm} \times 1.95 \mathrm{~mm}$ [1:6.5]), by a stigma about half as wide as the ovary (vs equaling the ovary in width), by pistillate florets each with an oblong staminode (vs pistillate florets lacking staminodes), by petioles entirely green not stained deep red in the lower half, and by leaf blades abaxially semi-glossy pale green (not slightly glaucous). From $H$. atrox, the only other species in NW Borneo with lanceolate leaf blades, H. santubongensis is immediately distinct in being entirely glossyglabrous (not microscopically pubescent), and by the smooth (not corrugated petiolar sheath).

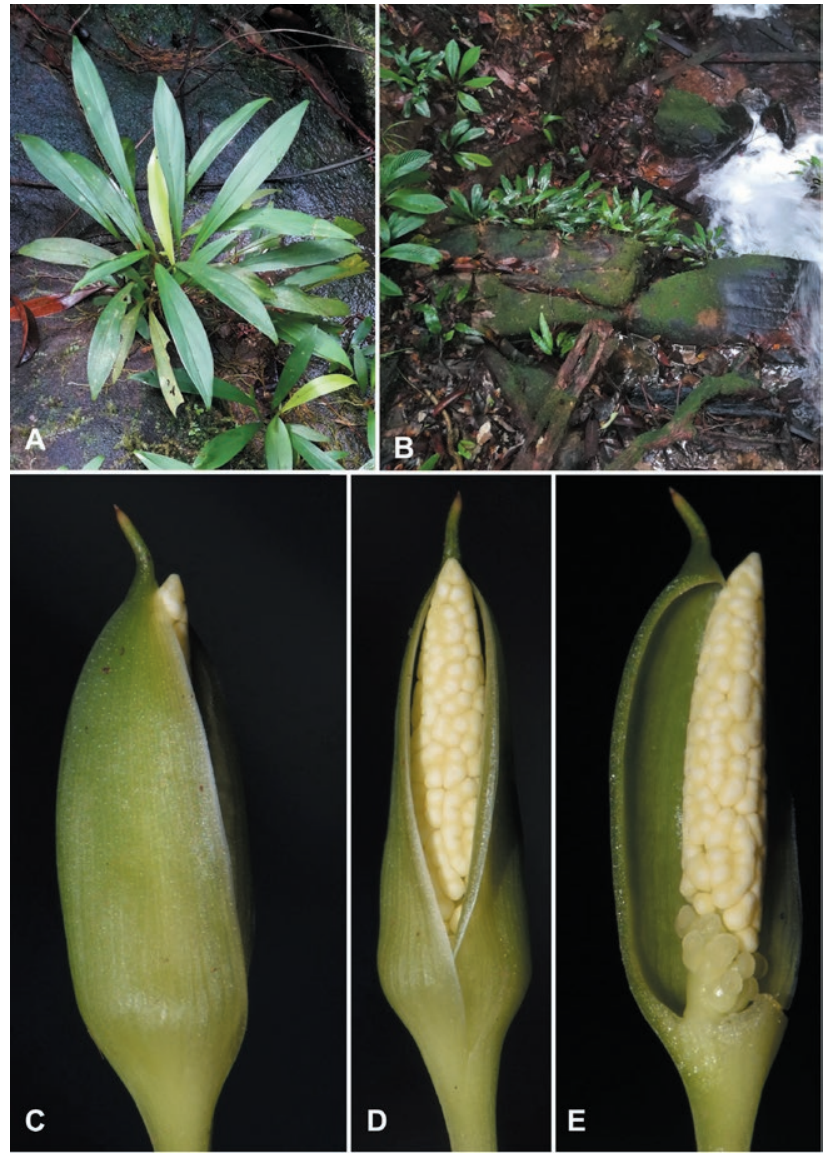

Figure 1. Homalomena santubongensis (A) Plant in habitat. (B) Habitat. (C \& D) Bloom at pistillate anthesis. (E) Bloom at late pistillate anthesis, nearside of spathe artificially removed. A, C-E from AR-2438.

\section{Description}

Small strongly aromatic (terpenoids) Steensian rheophytes (Boyce and Wong 2019: 505 et seq.) up to c. 13 $\mathrm{cm}$ tall. Stem epigeal, erect and congested, in older plants occasionally becoming somewhat elongated and decumbent with the active tip ascending, rooting from the lower-most nodes and through the petiole bases; roots c. 1-3 $\mathrm{mm}$ diam., tough, flexuous, pale brown, slightly velvety, highly adhesive to substrate. Leaves up to c. 15 together per shoot, petioles erect to spreading; petiole $4-10 \mathrm{~cm}$ long, c. $2 \mathrm{~mm}$ diam. midway, dorsally very narrowly channelled, bright medium green, glossy glabrous; petiolar sheath $1.5-3 \mathrm{~cm}$ long, extending c. $1 / 4$ length of the petiole, clasping at the base, width between both margins c. $1 \mathrm{~mm}$, wings persistent; leaf blade narrowly elliptic to oblong-lanceolate, $6-12 \mathrm{~cm}$ long by $2-3 \mathrm{~cm}$ wide, thinly coriaceous, glossy, glabrous, medium green adaxially, abaxially paler green with the higher order veins darker- 


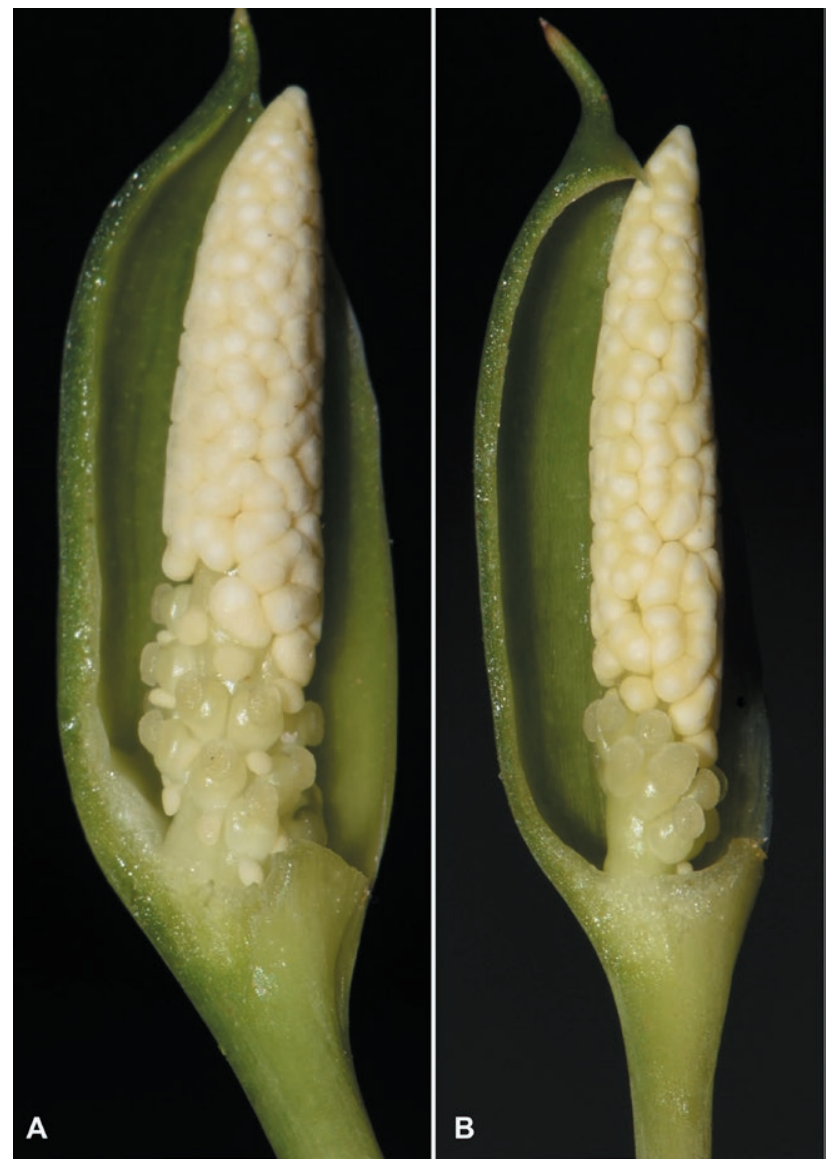

Figure 2. Spadix comparisons (A) Homalomena santubongensis and (B) Homalomena paucinervia.

translucent, base cuneate, apex acute to acuminate with a brief (c. $1.5 \mathrm{~mm}$ long) tubular mucro, margins smooth; midrib adaxially slightly impressed, abaxially prominent; primary lateral veins $4-6$ on each side of midrib, adaxially slightly impressed, abaxially alternating with much fainter much more numerous interprimaries, diverging at c. $40^{\circ}-60^{\circ}$ from the midrib; secondary and tertiary venation obscure; all veins running into a very slightly thickened intramarginal vein. Blooms up to 5 together, produced sequentially in a simple synflorescence; peduncle terete, slender, $2-5 \mathrm{~cm}$ long by c. $1 \mathrm{~mm}$ diam., coloured as for petiole; spathe ellipsoid, not constricted, at anthesis $2.2 \mathrm{~cm}$ long by $5-8 \mathrm{~mm}$ wide, with a terminal short mucro to 1-2 mm long, exterior glossy dark green with faint paler speckling, interior glossy medium green, spathe gaping at anthesis with the margins recurving and opening to expose the pistillate florets, closing post staminate anthesis and persisting until basal dehiscence at fruit dispersal. Spadix slightly exceeding spathe limb opening at anthesis, c. $1.9 \mathrm{~cm}$ long by c. $5 \mathrm{~mm}$ diam., shortly stipitate, stipe stout, c. $3 \mathrm{~mm}$ diam.; pistillate florets in two or three (incomplete) spirals, ovaries oblong-globose; stigmas about half as wide as ovary, ca. $0.3 \mathrm{~mm}$ diam., disc-like, sessile; associated staminodes oblong, sessile, cream, about tall as the ovary; staminate zone c. $1.5 \mathrm{~cm}$ long, apex acute; staminate florets each consisting of two stamens, anthers rounded, c. $0.5 \mathrm{~mm}$ tall, $1-1.5 \mathrm{~mm}$ long by $0.5-0.8 \mathrm{~mm}$ wide, dirty white with the tips pale; post anthesis blooms pendulous by bending of the peduncle. Infructescence ripening within the persistent spathe, exposed by the spathe shedding; fruit rather squat with the tops flattened by pressing on the spathe interior during development and the stigma impressed, whitish green with the stigma remnants brown, crushed fruits smelling faintly of overripe fruit/butyric acid; seed, very small, c. 1 $\mathrm{mm}$ long, oblong-ellipsoid, testa longitudinally ribbed.

\section{Etymology}

The species epithet is derived from the name of the type locality, plus the Latin suffix -ensis, indicating 'originating from'.

\section{Distribution}

Known only from the Santubong Peninsular where it is locally abundant.

Ecology

Rheophytic in the flood zone of relatively exposed Paleogene sandstone waterfalls and streambanks under humid lowland between 40-240 m asl.

Notes

With the addition of Homalomena santubongensis the described species of lanceolate-leaved Homalomena Chamaecladon clade now number three for NW Borneo. Although Homalomena paucinervia (Figure 3) is highly similar in overall appearance it is separated not only by the characteristics described here but also geographically and to an extent ecologically, with $H$. santubongensis restricted to the more open and somewhat drier Paleogene sandstones of the Santubong Peninsula, while $H$. paucinervia occurs on the much wetter Cretaceous sandstones of the Matang Massif. Homalomena atrox (Figure 4), from riverine shales on the Batang Ai drainages is distinct by the microscopically pubescent leaves and petioles.

The three species may be keyed out as follows:

1. Leaf blades and petioles microscopically pubescent; petiolar sheaths corrugated. Batang Ai drainage on shales.

Homalomena atrox 


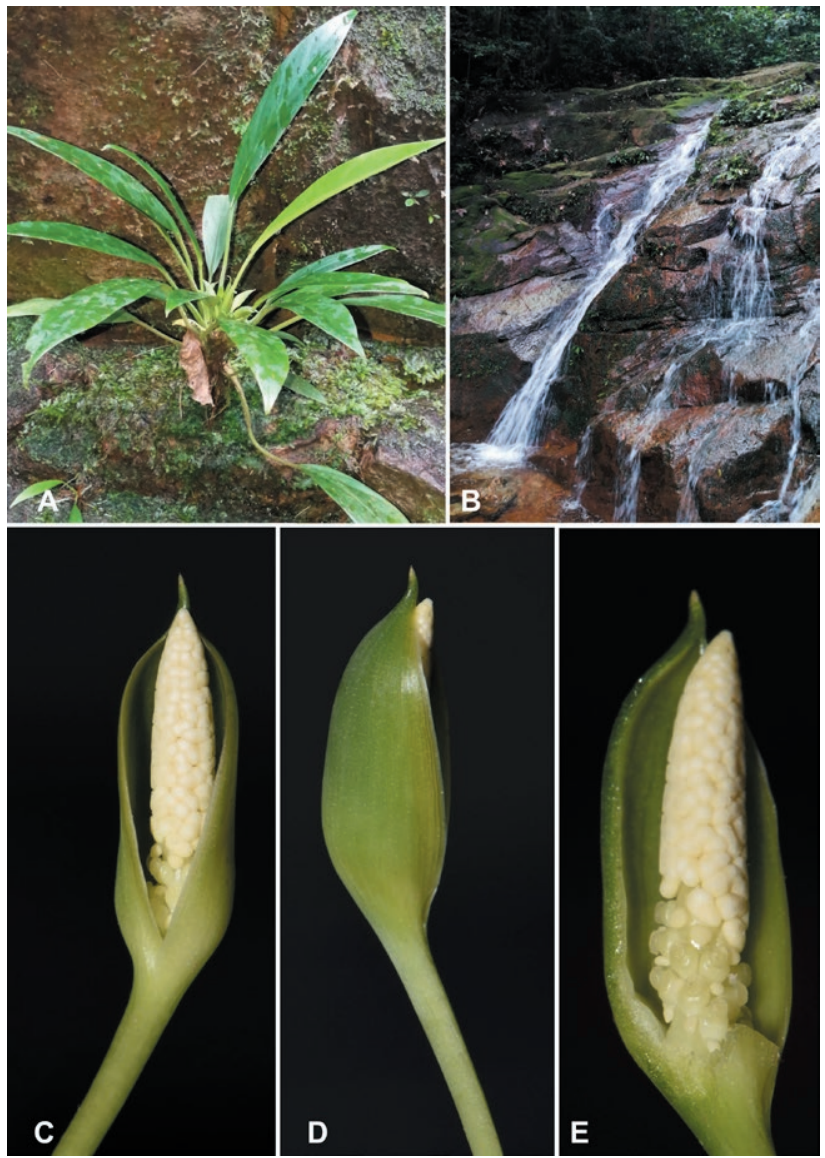

Figure 3. Homalomena paucinervia (A) Plant in habitat. (B) Habitat. (C \& D) Bloom at pistillate anthesis. (E) Bloom at late pistillate anthesis, nearside of spathe artificially removed. A, C-E from AR-2121.

Leaf blades and petioles not microscopically pubescent; petiolar sheaths smooth..... .2

2. Spathe opening wide to reveal the pistillate florets; spadix $4 \mathrm{~mm} \times 1.9 \mathrm{~cm}$ [1:4.5]; stigma about half as wide as the ovary; pistillate florets each with an oblong staminode, petioles entirely green; leaf blades abaxially semi-glossy pale green. Paleogene sandstones. Santubong......

Homalomena santubongensis

Spathe not opening wide enough to reveal the pistillate florets Spadix $3 \mathrm{~mm} \times 1.95 \mathrm{~mm}$ [1:6.5]), stigma equaling the ovary in width, pistillate florets lacking staminodes, petioles stained deep red in the lower half, leaf blades abaxially slightly glaucous. Cretaceous sandstones. Matang Massif

Homalomena paucinervia

\section{Additional specimen examined (paratypes)}

MALAYSIA: Sarawak, Kuching, Santubong N.P,. Summit Trail, Waterfall F5, 144’34.8”N 110¹9'19.9”E,

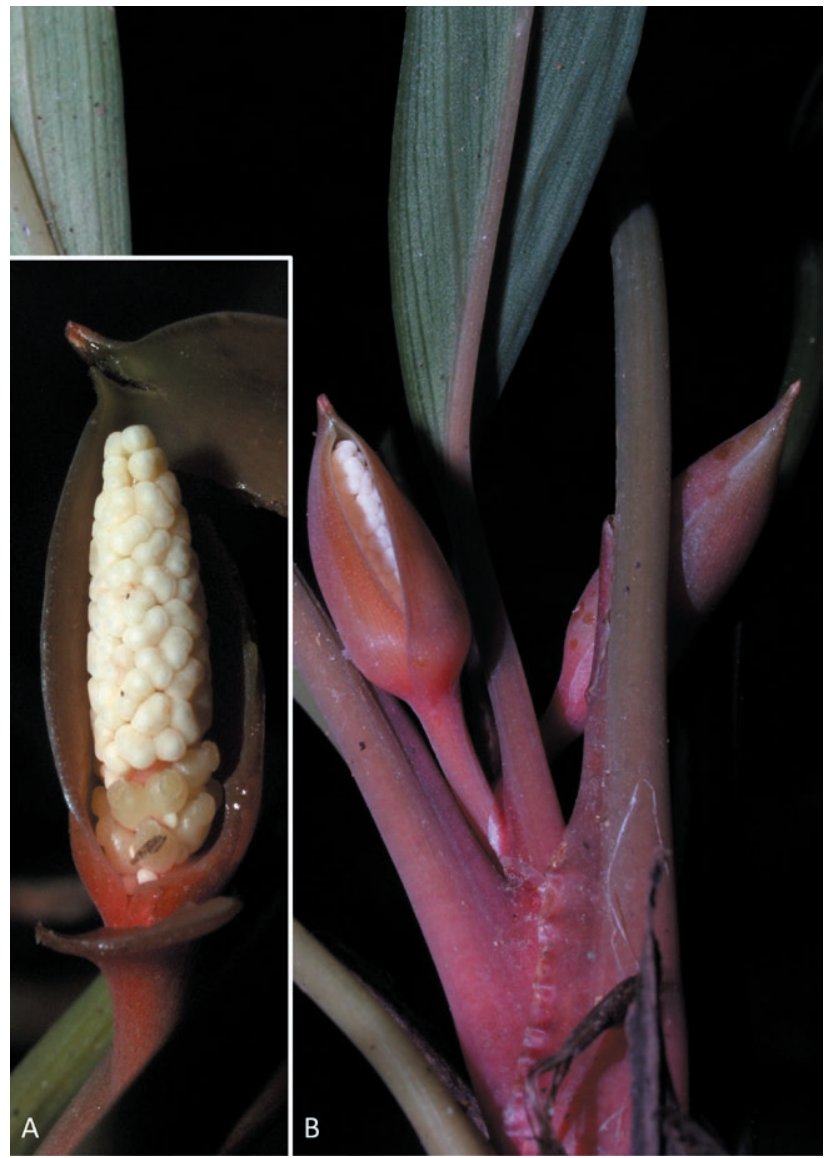

Figure 4. Homalomena atrox (A) Bloom at late pistillate anthesis, nearside of spathe artificially removed. (B). Flowering plant. All from $A R-2375$.

120 m asl., 22 Jul 2007 P.C.Boyce, Wong Sin Yeng \& S.Maclean AR-2104 (SAR).

\section{ACKNOWLEDGEMENTS}

The collaboration and support of the Sarawak Forestry Department and the Sarawak Biodiversity Centre are gratefully acknowledged. The second author extends his thanks to Tan Sri Datuk Amar Leonard Linggi Anak Jugah and Malesiana Tropicals Sdn Bhd for continued support and encouragement.

\section{REFERENCES}

Boyce PC, Croat TB. 2011 and onwards: The Überlist of Araceae, Totals for published and estimated number of species in aroid genera. doi: 10.13140/ RG.2.2.24820.09605 
Boyce PC, Wong SY. 2015. Studies on Schismatoglottideae (Araceae) of Borneo L - Schismatoglottis meriraiensis, a new limestone-obligated species with viviparous leaves. Telopea. 18: 443-450.

Boyce PC, Wong SY. 2019. Borneo and its disproportionately large rheophytic aroid flora. Gardens' Bulletin Singapore. 71(Suppl. 2): 497-524.

Boyce PC, Wong SY, Fasihuddin BA. 2010. Studies on Homalomeneae (Araceae) of Borneo II: The Homalomena of Nanga Sumpa (Batang Ai) - Novel \& pre-existing taxa, and notes on Iban Usages. Gardens' Bulletin Singapore. 61(2): 269-317.

Furtado CX. 1939. Araceae Malesicae: Notes on Some Indo-Malaysian Homalomena Species. Gardens' Bulletin, Straits Settlements. 10(2): 183-283.

Hay, A. 1998. The genus Alocasia (Araceae-Colocasieae) in West Malesia and Sulawesi. Gardens' Bulletin Singapore. 50: 221-334.

Hutchinson CS. 1989. Geological Evolution of South-East Asia. Oxford University Press, Malaysia.

Hutchinson CS. 2005. Geology of north-west Borneo: Sarawak, Brunei and Sabah. Elsevier, The Netherlands.

Kartini S. Boyce PC, Wong SY. 2015. Studies on Homalomeneae (Araceae) of Borneo XIX: Three new species of geologically obligated Homalomena from Sabah, Malaysian Borneo. Willdenowia. 45: 419-427.

Ridley HN. 1905. The Aroids of Borneo. Journal of the Straits Branch of the Royal Asiatic Society. 44: 169188.

Tate RB. 2001. The Geology of Borneo Island CD-ROM. Persatuan Geologi Malaysia: Geological Society of Malaysia.

Wong SY, Boyce PC. 2020. Studies on Homalomeneae (Araceae) of Borneo XXIV - Two new geologically-restricted species of Homalomena [Chamaecladon clade - Griffithii complex] from NW Borneo. Annales Botanici Fennici. 57: 285-292.

Wong SY, Boyce PC, Hay A. 2020. Studies on Homalomeneae (Araceae) of Sumatera VI: Two remarkable new species of Homalomena [Chamaecladon Clade]. Webbia. 75(1): 117-122

Wong SY, Tan PJ, Ng, KK, Othman AS, Lee HB, Ahmad FB, Boyce PC. 2013. Phylogeny of Asian Homalome$n a$ (Araceae) based on the ITS region combined with morphological and chemical data. Systematic Botany. 38: 589-599. 